\title{
The Association of Oxygen Saturation and Haemoglobin Level on Elderly
}

\author{
Joice Nancy Ansje Engka ${ }^{1 *}$, Hedison Polii ${ }^{1}$, Sylvia Ritta Marunduh ${ }^{1}$
}

${ }^{1}$ Faculty of Medicine, Sam Ratulangi University, Jl Kampus Unsrat, Bahu Manado 95115, Indonesia

DOI: $10.36347 /$ sjams.2022.v10i01.020

| Received: 13.12.2021 | Accepted: 19.01.2022 | Published: 26.01.2022

*Corresponding author: Joice Nancy Ansje Engka

Faculty of Medicine, Sam Ratulangi University, Jl Kampus Unsrat, Bahu Manado 95115, Indonesia

According to the World Health Organization (WHO), the elderly is a population group aged 60 years or more. In 2010 the number of elderly people was recorded at 18.1 million people or $17.6 \%$. In 2014 the number increased to 18.8 million people. The number in Indonesia is estimated to reach 28.8 million people or 11.34 percent of the total population in 2020. Data from Indonesia Basic Health Research 2018 showed that most of the elderly in Indonesia have degenerative diseases such as diabetes and heart disease [1]. In the 21st century, a special challenge in the health sector is the increasing number of elderly with degenerative problems and non-communicable diseases (NCDs) such as diabetes, hypertension, and mental health disorders (depression, dementia, anxiety disorders, and sleeping disorder). These diseases will cause serious problems if they are not addressed or if prevention is not carried out. This condition causes the elderly to be vulnerable to serious complications. Hemoglobin $(\mathrm{Hb})$ is an iron-rich protein in red blood cells whose function is to carry oxygen throughout the body. This protein also functions to give blood its red color. In order to function properly, the hemoglobin level in the blood must be within the normal range. Oxygen saturation is the fraction of hemoglobin oxygen saturation relative to the total hemoglobin in the blood. The human body requires and regulates a very precise and specific balance of oxygen in the blood. The normal arterial blood oxygen saturation level in humans is $95-100 \%$. Objective: The objective is to determine the relationship between oxygen saturation and Hemoglobin levels in the Elderly. Method: This study is an analytic observational study with a cross-sectional design. The research subjects are elderly people aged $\geq 60$ years who live in Malalayang Dua Village, Manado City. In this study, the reference value of normal oxygen saturation is $95-100 \%$ and the Reference Value of Hb based on WHO, men $<13 \mathrm{~g} / \mathrm{dL}$, non-pregnant women $<11 \mathrm{~g} / \mathrm{dL}$ Based on the analysis of the relationship using the Spearman correlation test, there is no relationship between oxygen saturation with hemoglobin level $(p=0.205$, where $p>\alpha$ or p>0.05). Conclusion: There is no relationship between oxygen saturation and hemoglobin levels in the elderly.

Keywords: Oxygen Saturation, Hemoglobin, Elderly.

Copyright $(\mathcal{C} 2022$ The Author(s): This is an open-access article distributed under the terms of the Creative Commons Attribution 4.0 International License (CC BY-NC 4.0) which permits unrestricted use, distribution, and reproduction in any medium for non-commercial use provided the original author and source are credited.

\section{INTRODUCTION}

Elderly (elderly) is someone aged 60 years who is still active in activities and work or those who are powerless in earning their own living so they depend on others to support themselves [2]. In Indonesia, the elderly in 2020 is estimated to reach 288 million people or 11.34 percent of the total population in the country. In the $21 \mathrm{st}$ century, the special challenges in the health sector are the increasing number of elderly people and the emergence of degenerative diseases and non-communicable diseases (NCDs) such as diabetes, hypertension, and mental health disorders, namely depression, dementia, anxiety disorders, sleeplessness [3].

Hemoglobin $(\mathrm{Hb})$ is an iron-containing protein molecule found in red blood cells, which can form a loose and reversible bond with $\mathrm{O}_{2}$ (7). The normal reference value for $\mathrm{Hb}$ based on $\mathrm{WHO}$ is male $<13$ $\mathrm{g} / \mathrm{dL}$, non-pregnant women $<11 \mathrm{~g} / \mathrm{dL}$ [4].

Oxygen saturation is a measure of how much oxygen percentage is able to bind to Hemoglobin in the bloodstream. The normal arterial blood oxygen saturation level in humans is $95-100 \%$ [5].

According to data from the Indonesia Central Statistics Agency (BPS) 2020, Life Expectancy in Indonesia during the COVID-19 Pandemic decreased by $0.18 \%$ in 2020 , whereas in the previous year, in 2019 , it was $0.20 \%$ [6].

\section{Materials ANd Methods}

This study is an analytical observational study with a cross-sectional design. This study was conducted for 10 months. The subjects of the study were elderly people aged 60-83 year old of total 117 people. 
Data collection techniques are:

a) Application for research permission as well as application for Ethical Clearance to the Research Ethics Committee Faculty of Medicine, Sam Ratulangi University, Manado.

b) Application for permission to the Malalayang Dua Village

c) Dissemination to the elderly regarding the purpose of this research with strict protocol

d) Interviews with prospective subjects to get the willingness to be a subject in this study by reading and signing the informed consent. e) Checking oxygen saturation with a pulse oximetry device and taking blood samples for hemoglobin level to be checked in laboratory.

\section{ReSults AND Discussion}

Blood samples were taken from 117 elderly who live in Malalayang Dua Village who have signed the informed consent. Normal oxygen saturation is 95$100 \%$ and the Reference Value for $\mathrm{Hb}$ levels is based on $\mathrm{WHO}$, men $<13 \mathrm{~g} / \mathrm{dL}$, non-pregnant women $<11 \mathrm{~g} /$ dL.

Table 1: Characteristics of Respondents by Age, Hemoglobin and Oxygen Saturation

\begin{tabular}{|l|l|l|l|l|}
\hline Characteristics & Minimum & Maximum & Mean & Std. Deviation \\
\hline Age (years) & 60 & 83 & 64.34 & 4.912 \\
\hline Hemoglobin (gr/dL) & 7.1 & 15.9 & 12.257 & 1.0612 \\
\hline Oxygen Saturation (\%) & 96 & 100 & 98.44 & 0.814 \\
\hline
\end{tabular}

The lowest age of respondent is 60 years and the highest is 83 years, the lowest $\mathrm{Hb}$ is $7.1 \mathrm{~g} / \mathrm{dL}$ and the highest is $15.9 \%$, the lowest oxygen saturation is $96 \%$ and the highest is $100 \%$.

Table 2. Correlation Analysis: Age, Hb and Oxygen Saturation Variables

\begin{tabular}{|c|c|c|c|c|c|}
\hline \multicolumn{6}{|l|}{ Correlations } \\
\hline & & & Age & Hemoglobin & $\begin{array}{l}\text { Oxygen } \\
\text { Saturation }\end{array}$ \\
\hline \multirow[t]{9}{*}{ Spearman's rho } & \multirow[t]{3}{*}{ Age } & Correlation Coefficient & 1.000 & -.153 & -.021 \\
\hline & & Sig. (2-tailed) & . & .100 & .822 \\
\hline & & $\mathrm{n}$ & 117 & 117 & 117 \\
\hline & \multirow[t]{3}{*}{ Hemoglobin } & Correlation Coefficient & -.153 & 1.000 & .118 \\
\hline & & Sig. (2-tailed) & .100 & & .205 \\
\hline & & $\mathrm{n}$ & 117 & 117 & 117 \\
\hline & \multirow[t]{3}{*}{ Oxygen Saturation } & Correlation Coefficient & -.021 & .118 & 1.000 \\
\hline & & Sig. (2-tailed) & .822 & .205 & $\cdot$ \\
\hline & & $\mathrm{n}$ & 117 & 117 & 117 \\
\hline
\end{tabular}

Based on the analysis of the relationship using the Spearman correlation test, there was no relation between hemoglobin levels and oxygen saturation $(p=0.205$, where $p>\alpha$ or $p>0.05)$.

This is the same as the research conducted by Suherlim D et al in 2018 on Professors aged 61-83 year old of Padjadjaran University Bandung [7].

\section{CONCLUSION}

There is no relationship between oxygen saturation and hemoglobin levels in the elderly in this study.

\section{ACKNOWLEDGEMENT}

Acknowledgments to Sam Ratulangi University which has provided grants for the implementation of this research, as well as to the elderly who live in the Malalayang Dua Village, Manado City, who have become the subjects of this research.

\section{REFERENCES}

1. Kementrian, K. R. (2018). Profil Kesehatan Indonesia
2017. Jakarta: Kemenkes RI. Diakses pada tanggal 31 Januari 2019 dari http://www.depkes.go.id/

2. World Health Organization. (2020). Tatalaksana klinis infeksi saluran pernapasan akut berat (SARI) suspek penyakit COVID-19. World Health Organ, 4(March), 125.

3. Nugroho, W. (2020). Komunikasi dalam Kepeawatan Gerontik, Jakarta: EGC.

4. World Health Organization (WHO). (2011). Haemoglobin concentration for the diagnosis of anaemia and assessment of severity. Vitamin and Mineral Nutrition information System, Genewa World Health Organization, $\quad$ (WHO/NMH/NHD/MNM/11.1) (http://www.who.int/wmnis/indicators/haemoglobin.pdf,

5. Tortora, G. J., \& Derrickson, B. (2014). TORTORA principles of anatomy physiology, 1-20.

6. Badan Pusat Statistik (BPS), Dampak Corona terhadap Umur Harapan Hidup di Indonesia. 15 Desember 2020 Kemenkes RI. Situasi Terkini Perkembangan (COVID19).

7. Suherlim, D., Lubis, L., \& Permana, H. (2018). Korelasi kadar hemoglobin dengan saturasi oksigen pada guru besar Universitas Padjadjaran. Bali Anatomy Journal, 1(2), 26-29. 